\title{
PENERAPAN MODEL PEMBELAJARAN KOOPERATIF TIPE NUMBERED HEADS TOGETHER (NHT) UNTUK MENINGKATKAN HASIL BELAJAR MATEMATIKA MATERI PECAHAN SISWA KELAS V SDN 50 BENGKALIS TAHUN PELAJARAN 2018/2019
}

\author{
Layla ${ }^{1}$ \\ 'Guru SDN 50 Bengkalis \\ layla.binti.ishak@gmail.com
}

\begin{abstract}
ABSTRAK Penelitian ini bertujuan untuk meningkatkan hasil belajar matematika materi pecahan siswa kelas V SDN 50 Bengkalis melalui penerapan model pembelajaran kooperatif tipe Numbered Heads Together (NHT). Bentuk penelitian yang dilakukan adalah penelitian tindakan kelas. Penelitian ini dilaksanakan dalam dua siklus. Prosedur penelitian yang dilaksanakan di kelas tindakan yaitu perencanaan, pelaksanaan, pengamatan dan refleksi. Data aktivitas dan nilai siswa diperoleh dari lembar pengamatan melalui observasi dan ulangan harian. Hasil penelitian menunjukkan peningkatan nilai rata-rata kelas, yaitu dari 58,57 pada data awal menjadi 77,32 pada siklus I dan 87,14 pada siklus II. Tingkat ketuntasan individu siswa juga mengalami peningkatan dari $28,57 \%$ menjadi $78,57 \%$ pada siklus I dan 92,86\% pada siklus II. Berdasarkan hasil penelitian tersebut dapat disimpulkan bahwa penerapan model pembelajaran kooperatif tipe NHT dapat meningkatkan hasil belajar matematika materi pecahan siswa Kelas V SDN 50 Bengkalis Tahun Pelajaran 2018/2019.
\end{abstract}

Kata-kata Kunci: Pembelajaran kooperatif tipe NHT, hasil belajar, matematika.

\section{PENDAHULUAN}

Matematika merupakan ilmu universal yang mendasari perkembangan teknologi modern, mempunyai peran penting dalam berbagai disiplin dan memajukan daya pikir manusia. Perkembangan pesat di bidang teknologi informasi dan komunikasi dewasa ini dilandasi oleh perkembangan matematika di bidang teori bilangan, aljabar, analisis, teori peluang dan matematika diskrit. Untuk menguasai dan mencipta teknologi dimasa depan diperlukan penguasaan matematika yang kuat sejak dini (BSNP, 2006).

Tujuan pembelajaran matematika adalah agar peserta didik memiliki kemampuan antara lain: (1) memahami konsep matematika, menjelaskan keterkaitan antar konsep dan mengaplikasikan konsep atau algoritma secara luwes, akurat, efisien dan tepat dalam pemecahan masalah; (2) menggunakan penalaran pada pola dan sifat, melakukan manipulasi matematika dalam membuat generalisasi, menyusun bukti atau menjelaskan gagasan dan pernyataan matematika; (3) memecahkan 
masalah yang meliputi kemampuan memahami masalah, merancang model matematika, menyelesaikan model dan menafsirkan solusi yang diperoleh; (4) mengkomunikasikan gagasan dengan simbol, tabel, diagram atau media lain untuk memperjelas keadaan atau masalah; (5) memiliki sikap menghargai kegunaan matematika dalam kehidupan, yaitu memiliki rasa ingin tahu, perhatian dan minat dalam matematika, serta sikap ulet dan percaya diri dalam pemecahan masalah (BSNP, 2006).

Tujuan pembelajaran tersebut dapat tercapai jika proses pembelajaran dikelola dengan baik. Guru memiliki peran yang sangat penting dalam mengelola proses pembelajaran. Pengelolaan proses pembelajaran merupakan salah satu komponen yang mempengaruhi keberhasilan pembelajaran (Yamin dan Ansari, 2009). Salah satu indikator keberhasilan pembelajaran adalah seberapa baik hasil belajar yang dicapai siswa setelah mengikuti proses pembelajaran.

Hasil belajar siswa kelas V SDN 50 Bengkalis belum menunjukkan hasil yang baik. Masih banyak siswa yang tidak tuntas. Dari 28 orang siswa yang mengikuti ulangan harian, terdapat $20(71,43 \%)$ siswa yang belum tuntas dan hanya $8(28,57 \%)$ siswa saja yang tuntas.

Salah satu faktor yang menyebabkan rendahnya hasil belajar matematika siswa adalah proses pembelajaran. Hasil refleksi diri terhadap proses pembelajaran selama ini diketahui bahwa proses pembelajaran didominasi oleh guru. Pembelajaran masih terpusat kepada guru. Secara umum pembelajaran yang biasa dilakukan guru adalah: membuka pelajaran dengan salam dan berdoa, lalu memulai pembelajaran dengan memberikan penjelasan dan contoh dipapan tulis, dilanjutkan dengan memberikan latihan kepada siswa, lalu membahas soal latihan, dan pelajaran ditutup.

Dalam proses pembelajaran seperti tersebut diatas, siswa yang aktif dalam belajar hanya siswa-siswa tertentu saja. Hanya sebagaian kecil siswa yang mengikuti pelajaran dengan semangat. Jika guru meminta siswa bertanya, siswa hanya diam. Jika guru meminta siswa untuk menjawab, sebagian siswa diam. Hanya siswa-siswa yang pintar saja yang mau menjawab. Proses pembelajaran belum maksimal dalam melibatkan seluruh siswa. Masih banyak siswa yang tidak terlibat aktif dalam pembelajaran.

Untuk menumbuhkan keaktifan para siswa dan melibatkan seluruh siswa di kelas untuk belajar, maka perlu proses pembelajaran yang sesuai. Salah satunya yaitu dengan penerapan model pembelajaran kooperatif tipe Numbered Head Together. Pembelajaran kooperatif merujuk pada berbagai macam metode pengajaran di mana para siswa bekerja dalam kelompok-kelompok kecil untuk saling membantu satu sama lainnya dalam mempelajari materi pelajaran (Slavin, 2010).

Penghargaan dalam pembelajaran kooperatif diberikan kepada kelompok berdasarkan prestasi semua anggota kelompok tersebut, bukan diberikan kepada individu. Sehingga apabila siswa ingin kelompoknya berhasil dan mendapatkan penghargaan yang tinggi, maka mereka akan mendorong anggota timnya untuk lebih baik dan akan membantu mereka untuk melakukannya (Slavin, 2010). Siswa dengan kemampuan rendah akan termotivasi untuk belajar karena dia memiliki 
kontribusi terhadap kelompoknya dan siswa yang berkemampuan tinggi dengan senang hati untuk mengajarkan temannya karena satu-satunya cara agar kelompok mereka sukses adalah jika semua anggota kelompok paham terhadap materi pelajaran. Hal ini akan menciptakan interaksi yang baik antar anggota kelompok. Model pembelajaran kooperatif yang dapat meningkatkan rasa tanggung jawab kelompok terhadap semua anggotanya adalah pembelajaran kooperatif tipe Numbered Heads Together. Terdapat 4 langkah pembelajaran pada model ini, yaitu penomoran, pengajuan pertanyaan, berpikir bersama, dan menjawab (Ibrahim, dkk, 2000). Pada kegiatan pengajuan pertanyaan, setiap siswa di dalam kelompok diberikan lembar soal yang harus dijawab bersama-sama. Hasil jawaban kelompok akan dipresentasikan di depan kelas. Siswa yang mempresentasikan jawaban kelompoknya dipanggil oleh guru dengan menggunakan nomor yang telah dibagikan. Hal ini berarti setiap siswa memiliki peluang yang sama untuk presentasi ke depan kelas.

Adanya peluang yang sama dan ketidaktahuan siapa yang akan tampil, membuat setiap siswa mempersiapkan dirinya dan juga temannya untuk tampil mewakili kelompok mereka dengan cara menyakinkan setiap anggota kelompok telah memahami materi dan mampu menjawab soal. Hal ini membuat siswa yang telah mengerti dan bisa menjawab soal akan dengan senang hati untuk berbagi pengetahuan kepada teman sekelompoknya. Tidak lagi khawatir akan menjadi saingan dalam merebutkan nilai tambah. Barangkali yang lebih penting adalah, mereka saling mendukung untuk berhasil, bukannya untuk gagal (Slavin, 2010). Dengan demikian maka pembelajaran dan diskusi kelompok akan berjalan aktif dan efektif sehingga pada akhirnya hasil belajar siswa dapat meningkat.

Penelitian ini dilakukan untuk meningkatkan hasil belajar matematika materi pecahan siswa kelas V SDN 50 Bengkalis Tahun Pelajaran 2018/2019 melalui penerapan model pembelajaran kooperatif tipe numbered head together.

\section{METODE PENELITIAN}

Bentuk penelitian yang dilakukan adalah Penelitian Tindakan Kelas (PTK). PTK merupakan bentuk kajian yang sistematis refleksif yang dilakukan oleh pelaku tindakan (guru) dan dilakukan untuk memperbaiki kondisi pembelajaran baik proses maupun hasil pembelajaran yang terjadi pada siswa (Amin, 2011). Wiriaatmadja (2005) mengatakan bahwa Penelitian Tindakan Kelas adalah bagaimana sekelompok guru dapat mengorganisasikan kondisi praktek pembelajaran mereka, dan belajar dari pengalaman mereka sendiri. Arikunto, dkk (2010) menyatakan bahwa PTK merupakan suatu pencermatan terhadap kegiatan belajar berupa sebuah tindakan yang sengaja dimunculkan dan terjadi dalam sebuah kelas secara bersama. Tindakan tersebut diberikan oleh guru atau arahan dari guru yang dilakukan oleh siswa. Berdasarkan paparan di atas dapat disimpulkan bahwa PTK adalah suatu penelitian berupa tindakan nyata yang dilakukan oleh peneliti (guru) untuk memecahkan permasalahan dalam pembelajaran melalui perbaikan proses pembelajaran untuk meningkatkan kualitas pembelajaran. 
Arikunto, dkk (2010) menyatakan bahwa secara garis besar penelitian tindakan kelas dilaksanakan melalui empat tahapan yang lazim dilalui, yaitu (1) perencanaan, (2) pelaksanaan, (3) pengamatan, (4) refleksi. Berpandu pada pernyataan Arikunto di atas model siklus penelitian tindakan kelas yang digunakan pada penelitian ini adalah sebagai berikut.
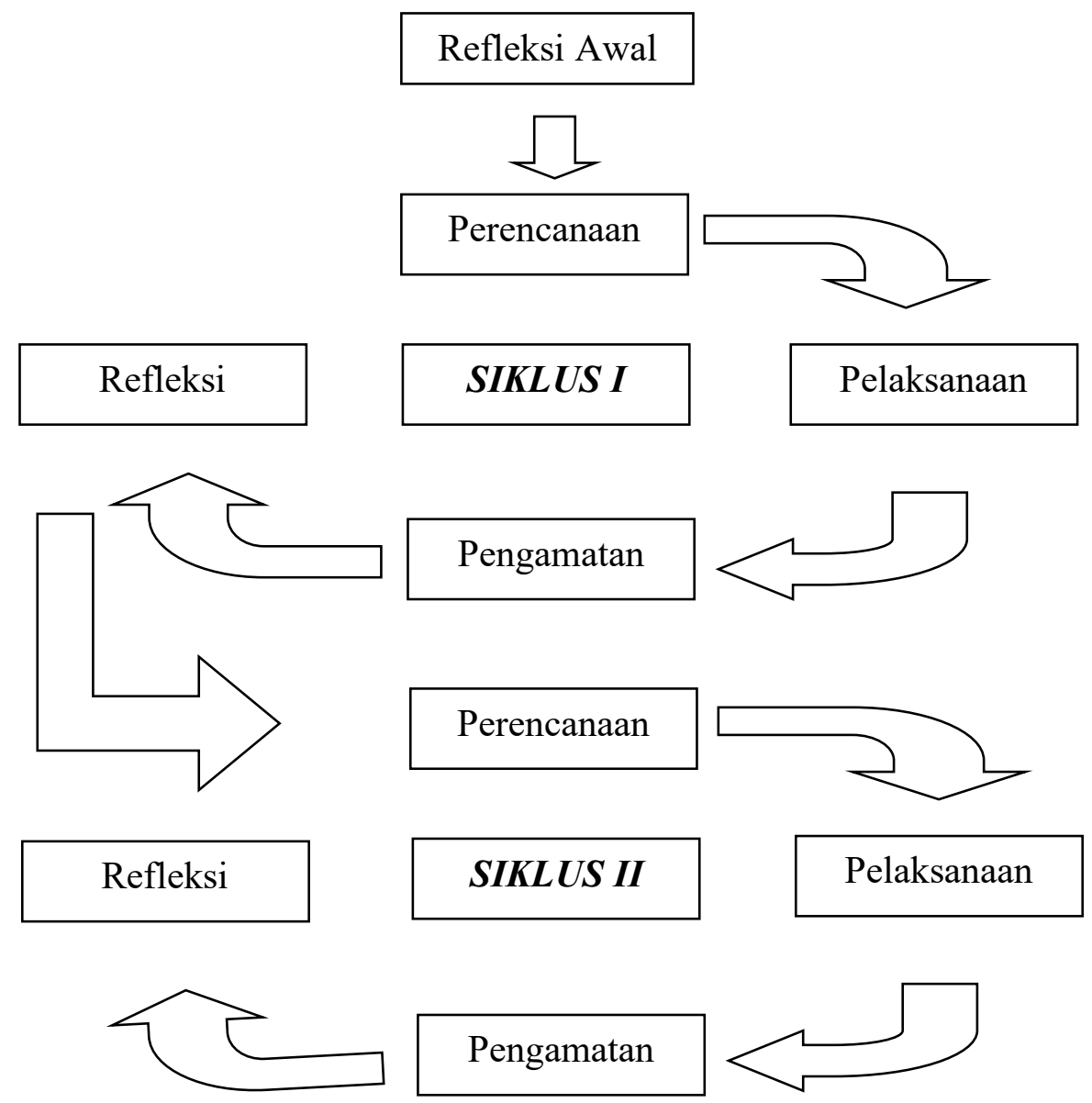

\section{Gambar 1 Siklus Penelitian Tindakan Kelas}

Subjek penelitian ini adalah siswa kelas V SD Negeri 50 Bengkalis Tahun Pelajaran $2018 / 2019$ yang berjumlah 28 orang. Penelitian ini dilaksanakan pada bulan Juli sampai dengan Oktober 2018.

\section{HASIL DAN PEMBAHASAN}

Penelitian Tindakan Kelas (PTK) dengan setting SDN 50 Bengkalis ini, pelaksanaannya mengikuti alur sebagai berikut:

\section{Perencanaan}

Meliputi penetapan materi pembelajaran matematika, penetapan alokasi waktu pelaksanaannya, dan pembuatan instrumen penelitian.

2. Pelaksanaan (Tindakan)

Meliputi seluruh proses kegiatan belajar mengajar menggunakan model pembelajaran kooperatif tipe numbered heads together. 
3. Observasi

Dilaksanakan bersamaan dengan proses pembelajaran, meliputi aktifitas guru dalam pembelajaran dan peningkatan partisipasi siswa dalam pembelajaran.

4. Refleksi

Meliputi kegiatan analisis proses dan hasil pembelajaran, serta menyusun rencana perbaikan pada siklus berikutnya.

Pelaksanaan penelitian dilakukan secara kolaboratif antara guru matematika (peneliti) dengan guru matematika yang lain dalam satu sekolah, yang membantu pelaksanaan observasi dan refleksi selama penelitian berlangsung, sehingga kegiatan penelitian ini dapat terkontrol untuk menjaga validitas hasil penelitian.

\section{Siklus I}

Siklus I dilaksanakan selama 3 pertemuan pembelajaran dan 1 pertemuan sebagai tes/ ulangan harian. Terdapat empat tahapan yang dilaksanakan pada siklus I yaitu: 1. Perencanaan

Tahap perencanaan merupakan tahap dimana peneliti menyiapkan segala kebutuhan yang diperlukan selama penelitian. Adapun yang dibutuhkan selama penelitian adalah perangkat pembelajaran dan instrumen pengumpul data. Perangkat pembelajaran terdiri dari silabus, RPP yang disusun untuk tiga kali pertemuan, dan LKS yang dibuat untuk tiga kali pertemuan. Instrumen pengumpul data yang digunakan adalah lembar pengamatan aktivitas guru dan siswa dan perangkat tes hasil belajar matematika untuk ulangan harian.

Pada tahap perencanaan ini peneliti membentuk kelompok belajar yang anggotanya heterogen dari segi akademik. Peneliti membagi siswa di kelas tersebut ke dalam tujuh kelompok yang masing-masing kelompok beranggota 4 orang.

2. Pelaksanaan Tindakan

Pelaksanaan tindakan dilakukan dengan menerapkan model pembelajaran kooperatif tipe Numbered Heads Together (NHT). Pelaksanaan pembelajaran dengan model kooperatif tipe NHT ini dilakukan sebanyak 3 pertemuan pembelajaran.

\section{Observasi}

Observasi dilakukan bersamaan dengan pelaksanaan proses pembelajaran. Observasi bertujuan untuk melihat aktivitas guru dan partisipasi siswa dalam pembelajaran. Observasi dilaksanakan oleh observer yang merupakan guru matematika teman sejawat peneliti. Kegiatan yang dilakukan pada tahap ini adalah

a. Mengamati partisipasi dan kreativitas siswa dalam pembelajaran

b. Mengamati guru dalam aktivitas pembelajaran

c. Mengamati pengelolaan kelas

d. Mengamati respon siswa terhadap pembelajaran

4. Refleksi

Kegiatan refleksi dilakukan untuk mengevaluasi proses pembelajaran yang telah dilakukan. Hasil refleksi digunakan untuk melakukan perbaikan pada siklus berikutnya. Beberapa hasil refleksi adalah sebagai berikut:

a. Sebagian besar kegiatan pembelajaran telah berjalan baik. 
b. Sebagian besar siswa telah terlibat dalam pembelajaran dengan baik, namun masih ada beberapa siswa yang belum terlibat aktif.

c. Beberapa siswa masih mencontoh jawaban temannya.

d. Siswa masih membicarakan hal-hal diluar pembelajaran didalam kelompok.

Untuk meningkatkan aktifitas dan keterlibatan siswa pada siklus berikutnya, peneliti berinisiatif untuk lebih memantau jalannya diskusi dan memberikan hadiah kepada siswa atau kelompok yang paling aktif.

\section{SIKLUS II}

Siklus II dilaksanakan selama 3 pertemuan pembelajaran dan 1 pertemuan sebagai tes / ulangan harian. Terdapat empat tahapan yang dilaksanakan pada siklus II yaitu: 1. Perencanaan

Tahap perencanaan merupakan tahap dimana peneliti menyiapkan segala kebutuhan yang diperlukan selama penelitian. Adapun yang dibutuhkan selama penelitian adalah perangkat pembelajaran dan instrumen pengumpul data. Perangkat pembelajaran terdiri dari silabus, RPP yang disusun untuk tiga kali pertemuan, dan LKS yang dibuat untuk tiga kali pertemuan. Instrumen pengumpul data yang digunakan adalah lembar pengamatan aktivitas guru dan siswa dan perangkat tes hasil belajar matematika untuk ulangan harian. Penyusunan perangkat dan instrumen penelitian pada siklus II ini didasarkan pada hasil refleksi siklus I.

2. Pelaksanaan Tindakan

Pelaksanaan tindakan dilakukan dengan menerapkan model pembelajaran kooperatif tipe Numbered Heads Together (NHT). Pelaksanaan pembelajaran dengan model kooperatif tipe NHT ini dilakukan sebanyak 3 pertemuan pembelajaran.

3. Observasi

Observasi dilakukan bersamaan dengan pelaksanaan proses pembelajaran. Observasi bertujuan untuk melihat aktivitas guru dan partisipasi siswa dalam pembelajaran. Observasi dilaksanakan oleh observer yang merupakan guru matematika teman sejawat peneliti. Kegiatan yang dilakukan pada tahap ini adalah

a. Mengamati partisipasi dan kreativitas siswa dalam pembelajaran

b. Mengamati guru dalam aktivitas pembelajaran

c. Mengamati pengelolaan kelas

d. Mengamati respon siswa terhadap pembelajaran

4. Refleksi

Kegiatan refleksi dilakukan untuk mengevaluasi proses pembelajaran yang telah dilakukan. Hasil refleksi digunakan untuk melihat keberhasilan pelaksanaan tindakan.

Beberapa hasil refleksi pada siklus II adalah sebagai berikut:

a. Kegiatan pembelajaran telah berjalan baik sesuai dengan RPP yang dibuat.

b. Siswa terlibat aktif dan pembelajaran dan diskusi kelompok

c. Pemahaman siswa terhadap pembelajaran terlihat semakin membaik yang ditandai dengan mampunya siswa mempresentasikan hasil diskusi dengan lancar dan baik. 


\section{Deskripsi dan Analisis Data Hasil Penelitian}

Penerapan model pembelajaran kooperatif tipe Numbered Heads Together dilaksanakan selama dua siklus yang masing-masing terdiri dari 3 pertemuan pembelajaran. Penerapan pembelajaran semakin baik dari pertemuan pertama ke pertemuan-pertemuan berikutnya. Selama proses pembelajaran juga dilakukan pengamatan oleh teman sejawat.

Penerapan pembelajaran kooperatif tipe NHT mampu membuat proses pembelajaran menjadi lebih baik. hal ini ditandai dengan keaktifan siswa dalam belajar. Siswa juga terlibat aktif dalam diskusi kelompok dan saling bertanya maupun menjawab saat presentasi kelompok.

Selain mampu meningkatkan kualitas proses pembelajaran, model kooperatif tipe NHT juga mampu memberikan hasil belajar yang lebih baik dari sebelumnya. Berdasarkan hasil tes pada siklus I dan siklus II diperoleh nilai siswa yang semakin meningkat. Hasil tes tersebut dapat dilihat pada tabel berikut ini.

Tabel 1. Data Ketuntasan Hasil Belajar Individu Siswa

\begin{tabular}{|c|c|c|c|c|}
\hline \multirow{2}{*}{ No } & \multirow{2}{*}{ Hasil Belajar } & \multicolumn{2}{|c|}{ Ketuntasan Individu } & \multirow{2}{*}{$\begin{array}{c}\text { Rata-rata } \\
\text { Nilai }\end{array}$} \\
\hline & & Tuntas & Tidak Tuntas & \\
\hline 1 & Data Awal & 8 orang $(28,57 \%)$ & 20 orang $(71,43 \%)$ & 58,57 \\
\hline 2 & Siklus I & 22 orang $(78,57 \%)$ & 6 orang $(21,43 \%)$ & 77,32 \\
\hline 3 & Siklus II & 26 orang $(92,86 \%)$ & 2 orang $(7,14 \%)$ & 87,14 \\
\hline
\end{tabular}

Untuk lebih jelasnya, perbandingan antara siswa yang tuntas dengan yang tidak tuntas dapat dilihat pada grafik berikut.

\section{Data Ketuntasan Individu}

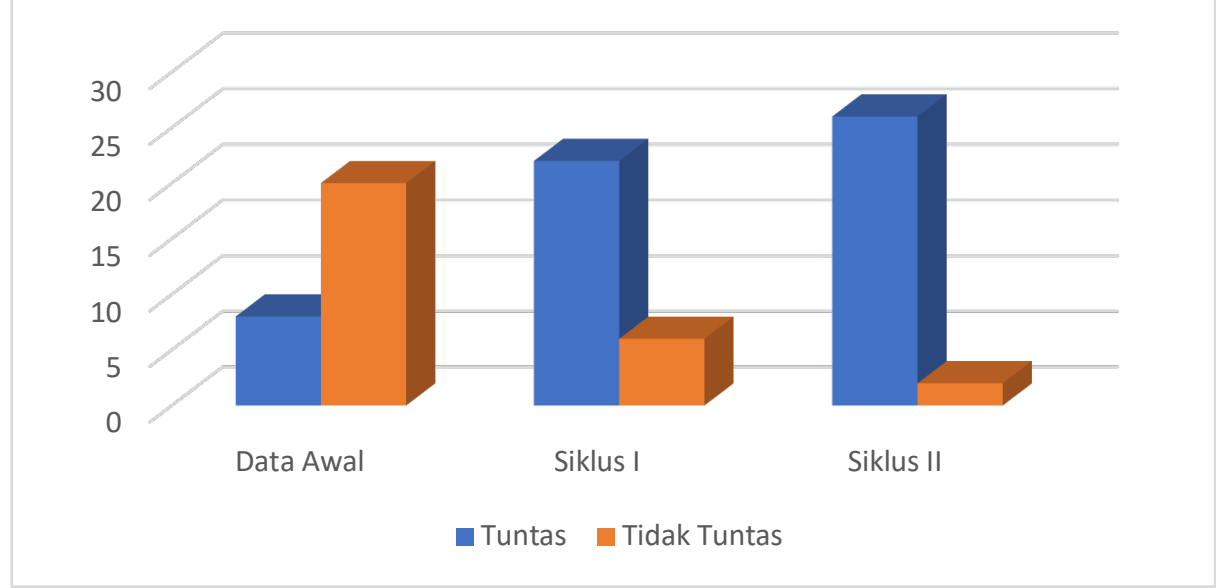

Grafik 1. Data Ketuntasan Individu

Berdasarkan nilai pada tabel dan grafik diatas dapat diketahui bahwa jumlah siswa yang tuntas semakin naik dari data awal ke siklus I dan dari siklus I ke siklus II. Selian itu terjadi juga peningkatan rata-rata nilai kelas pada siklus I dan siklus II. Hal ini menjadi indikator keberhasilan pelaksanaan pembelajaran dengan menerapkan model pembelajaran kooperatif tipe NHT. 
Berikut ini disajikan sebaran nilai yang diperoleh siswa pada saat sebelum penerapan pembelajaran kooperatif tipe NHT dan setelah penerapan (siklus I dan siklus II).

Tabel 2. Sebaran Nilai Siswa

\begin{tabular}{llcccccc}
\hline No & Kategori & Data Awal & $\%$ & Siklus I & $\%$ & Siklus II & $\%$ \\
\hline 1 & $\begin{array}{l}\text { Baik Sekali } \\
(90-100)\end{array}$ & 0 & 0,00 & 3 & 10,71 & 14 & 50,00 \\
\hline 2 & $\begin{array}{l}\text { Baik } \\
(80-89)\end{array}$ & 2 & 7,14 & 14 & 50,00 & 11 & 39,29 \\
\hline 3 & $\begin{array}{l}\text { Cukup } \\
(70-79)\end{array}$ & 6 & 21,43 & 5 & 17,86 & 1 & 3,57 \\
\hline 4 & $\begin{array}{l}\text { Kurang } \\
(60-69)\end{array}$ & 8 & 28,57 & 6 & 21,43 & 2 & 7,14 \\
\hline 5 & $\begin{array}{l}\text { Sangat } \\
\text { Kurang } \\
(0-59)\end{array}$ & 12 & 42,86 & 0 & 0,00 & 0 & 0,00 \\
\hline
\end{tabular}

Untuk lebih jelasnya, sebaran nilai siswa dapat dilihat pada grafik berikut.

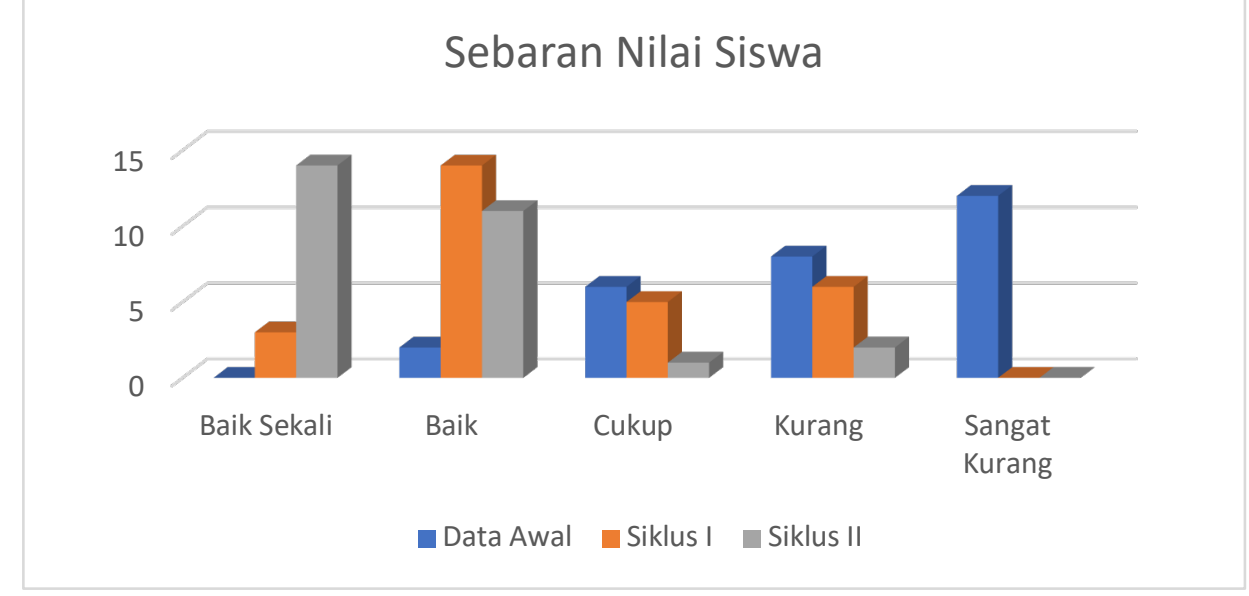

\section{Grafik 2. Sebaran Nilai Siswa}

Berdasarkan data pada tabel dan grafik diatas dapat diketahui bahwa sebelum penerapan model pembelajaran kooperatif tipe NHT, nilai siswa berada paling banyak pada kategori "sangat kurang" yaitu $42,86 \%$ serta tidak ada satu siswapun yang berada pada kategori "sangat baik". Setelah penerapan pembelajaran kooperatif tipe NHT, terjadi peningkatan nilai siswa yang ditandai dengan tidak adanya siswa yang berada pada kategori "sangat kurang" baik pada siklus I maupun siklus II. Selain itu terdapat peningkatan banyak siswa yang berada pada kategori "sangat baik", dari yang sebelumnya $0 \%$ menjadi $10,71 \%$ pada siklus I dan $50 \%$ pada siklus II. Hal ini menjadi indikator keberhasilan pelaksanaan pembelajaran kooperatif tipe NHT dalam meningkatkan hasil belajar siswa.

Berdasarkan hasil penelitian yang telah dipaparkan sebelumnya terlihat bahwa penerapan model pembelajaran kooperatif tipe NHT berhasil dalam meningkatan hasil belajar siswa. Keberhasilan ini ditandai dengan beberapa hal. Pertama, meningkatnya nilai rata-rata kelas, yaitu dari 58,57 pada data awal menjadi 77,32 pada siklus I dan 87,14 pada siklus II. Kedua, terjadinya peningkatan banyak siswa yang tuntas, yaitu dari 8 orang pada data awal menjadi 22 orang pada siklus I dan 
26 orang pada siklus II. Ketiga, semakin banyaknya nilai siswa yang berada pada kategori sangat baik, yaitu dari 0 siswa pada data awal menjadi 3 orang pada siklus I dan 14 orang pada siklus II, serta berkurangnya nilai siswa yang berada pada kategori sangat kurang, yaitu dari 12 orang pada data awal menjadi tidak ada pada siklus I dan siklus II.

Keberhasilan penerapan model pembelajaran kooperatif tipe NHT ini dikarenakan proses pembelajaran pada model ini yang mampu meningkatkan aktifitas belajar siswa. Pada model ini siswa dituntut untuk memahami materi dengan baik. pemanggilan nomor untuk tampil dalam menjawab soal membuat siswa termotivasi dalam belajar. Siswa merasa khawatir jika dia tidak menjawab ketika nomornya disebutkan. Hal ini membuat siswa tersebut bertanya kepada teman sekelompoknya. Pembelajaran berkelompok membuat siswa bisa saling bertukar pikiran dan saling mengajarkan materi. Hal ini pada akhirnya membuat hampir semua siswa paham dengan materi yang sedang diajarkan. Sehingga nilai siswa semakin meningkat.

\section{KESIMPULAN DAN SARAN}

Berdasarkan hasil penelitian yang diperoleh dapat disimpulkan bahwa penerapan model pembelajaran kooperatif tipe numbered heads together (NHT) dapat meningkatkan hasil belajar matematika materi pecahan siswa kelas $V$ SDN 50 Bengkalis tahun pelajaran 2018/2019. Selain peningkatan nilai, terdapat juga peningkatan aktifitas dan semangat belajar siswa.

Peningkatan hasil belajar matematika siswa ditandai dengan peningkatan nilai ratarata kelas, yaitu dari 58,57 pada data awal menjadi 77,32 pada siklus I dan 87, 14 pada siklus II. Tingkat ketuntasan individu siswa juga mengalami peningkatan dari $28,57 \%$ menjadi 78,57\% pada siklus I dan 92,86\% pada siklus II.

Berdasarkan hasil penelitian yang telah dilakukan, dapat diberikan beberapa saran sebagai berikut: 1) Guru hendaknya senantiasa memperbaiki proses pembelajaran di kelas untuk meningkatkan kemampuan siswa baik dari segi kognitif, afektif, maupun psikomotor. 2) Pembelajaran yang diterapkan hendaknya mengedepankan aktifitas belajar siswa, bukan terfokus pada guru. 3) Guru harus memiliki manajemen kelas yang baik agar dapat menciptakan suasana kondusif ketika belajar.

\section{DAFTAR PUSTAKA}

Alwi, H., 2002, Kamus Besar Bahasa Indonesia, Edisi Ketiga, Jakarta: Balai Pustaka.

Amin,Moh., 201 1, Panduan Praktis Penelitian Tindakan Kelas, Yogyakarta :Inspirasi.

Arikunto, S., Suhardjono, Supardi., 2010, Penelitian Tindakan Kelas, Jakarta: Bumi Aksara.

BSNP., 2006, Panduan Penyusunan Kurikulum Tingkat Satuan Pendidikan Jenjang Pendidikan Dasar dan Menengah, Jakarta: Depdiknas.

Dimyati dan Mudjiono., 2006, Belajar dan Pembelajaran, Jakarta: Rineka Cipta.

Gulo, W., 2005, Strategi Belajar Mengajar, Jakarta: Grasindo. 
Hamalik, O., 2004, Perencanaan Pengajaran Berdasarkan Pendekatan Sistem, Jakarta: Bumi Aksara.

Hudojo, H., 1990, Strategi Mengajar Belajar Matematika, Malang: IKIP Malang.

Ibrahim, M., Fida, R., Mohamad, N., Ismono, 2000, Pembelajaran Kooperatif, Surabaya: University Pers.

Slameto., 2010, Belajar dan Faktor- Faktor yang Mempengaruhi, Jakarta: Rineka Cipta.

Slavin, R.E., 1995, Cooperative Learning, Theory Research and Practise, Boston: Ally and Bacon.

Slavin, R.E., 2010, Cooperative Learning, Teori, Riset dan Praktik, Terjemahan Lita, Bandung: Nusa Media.

Sudjana, N., 2005, Penilaian Hasil Proses Belajar Mengajar, Bandung: Remaja Rosdakarya.

Suprijono, A., 2010, Cooperative Learning, Yogyakarta: Pustaka Pelajar.

Trianto., 2007, Model-Model Pembelajaran Inovatif Berorientasi Konstruktivistik, Konsep, Landasan Teoritis-Praktis dan Implementasinya, Jakarta: Prestasi Pustaka.

Wiriaatmadja, Rochiati., 2005, Metode Penelitian Tindakan Kelas, Bandung: Remaja Rosdakarya.

Yamin, M., dan Ansari,B.I., 2009, Taktik Mengembangkan Kemampuan Individual Siswa, Jakarta: Gaung Persada Press. 